\title{
Article \\ Trawler Engine Size Had No Effect on Baltic Herring Size/Age Structure: An Experimental Study in the Gulf of Riga, Baltic Sea
}

\author{
Elor Sepp *D, Markus Vetemaa, Tiit Raid and Timo Arula
}

\author{
Estonian Marine Institute, University of Tartu, Mäealuse 14, 12618 Tallinn, Estonia; markus.vetemaa@ut.ee (M.V.); \\ tiit.raid@ut.ee (T.R.); timo.arula@ut.ee (T.A.) \\ * Correspondence: elor.sepp@ut.ee
}

check for updates

Citation: Sepp, E.; Vetemaa, M.; Raid, T.; Arula, T. Trawler Engine Size Had No Effect on Baltic Herring Size/Age Structure: An Experimental Study in the Gulf of Riga, Baltic Sea. Fishes 2022, 7, 46. https://doi.org/10.3390/ fishes7010046

Academic Editor: Yongjun Tian

Received: 6 January 2022

Accepted: 10 February 2022

Published: 12 February 2022

Publisher's Note: MDPI stays neutral with regard to jurisdictional claims in published maps and institutional affiliations.

Copyright: (C) 2022 by the authors. Licensee MDPI, Basel, Switzerland. This article is an open access article distributed under the terms and conditions of the Creative Commons Attribution (CC BY) license (https:// creativecommons.org/licenses/by/ $4.0 /)$.

\begin{abstract}
The Gulf of Riga stock of Baltic herring (Clupea harengus membras L.) has been maintained through several management tools. One such tool is the restriction of vessels' main engine power $(<221 \mathrm{~kW})$. This restriction was implemented in the early 1990s and is based on the vessel types available in the area and on the assumption that the gear size used in trawl fishery depends on the vessel size (power). In the current study, we compared vessels with different engine powers using the same gears currently allowed in the gulf, to identify whether vessel power had any relation to catch structure. The results showed that engine power did not explain the differences in catch structure, which were more dependent on season and depth of water. Easing the power restriction of the trawl vessels in the Gulf of Riga will most likely not have a major negative impact on the sustainable management of the herring population. However, vessels with higher engine power should not use larger trawl gear than is currently used in the gulf.
\end{abstract}

Keywords: herring fishery; engine effect; Gulf of Riga; Baltic sea; Baltic herring

\section{Introduction}

The management success of fish stocks depends on the availability and reliability of knowledge surrounding the biological specifics of the stock, as well as on fishery-dependent information. In a situation where most of the known commercial fish stocks in the world are fully exploited or overexploited, management improvements are urgently needed [1-3]. Mortality caused by fishery is a significant factor affecting fish stock abundance, playing a key role in fisheries' management. The mortality information may be biased for several reasons (discarding, gear selection, escapee mortality, misreporting, etc.) [4,5]. The European common fisheries policy (CFP) has implemented a ban on discarding, to reduce unaccounted mortality [6] and to incentivize the fishing sector towards more sustainable fishing practices. The ultimate goal of all fisheries' managers, as well as fishermen, is to catch only target species and target size classes. Higher selectivity, as a key component in achieving this goal, can be difficult because of the hidden mortality of juveniles escaping through the trawl meshes [4,5,7-9].

The Baltic herring (Clupea harengus membras L.) has a number of local populations with different biological characteristics [10-12]. The Gulf of Riga (ICES Subdivision 28.1) herring is spatially relatively well isolated from the other Baltic herring populations, and its stock dynamics have been well monitored since the 1970s [12,13]. The stocks of the Gulf of Riga and the Central Baltic herring have exhibited inverse development since the 1970s: while the latter decreased, the Gulf of Riga (GoR) stock displayed a series of very high recruitment events, showed an increasing trend in the 1990s, and has remained at a high level since then $[14,15]$. High fishing mortality $(F)$ has been identified as an issue in GoR herring management, periodically exceeding the agreed $\mathrm{F}_{\mathrm{MSY}}$ (fishing mortality consistent with achieving maximum sustainable yield) [15]. The spatial aggregation of herring differs slightly according to the seasons. During winter, the fish concentrate into layers limited 
by temperature $\left(2-6^{\circ} \mathrm{C}\right)$ from above. Young herring and sprat dominate the upper section while older herring reside in the lower layers. With the rise of temperature in the spring, younger herring ascend to the warmer surface layer while older herring remain in the bottom layers. A similar distribution pattern occurs in summer, smaller individuals tend to dominate the higher levels of the water column [16].

Herring fishery in the GoR is performed by Estonian and Latvian fishermen, using both trawls and trap-nets. Trawl fishery takes place throughout the year during the ice-free period, while coastal trap-net fishery focuses on the pre-spawning and spawning periods, ranging from the melting of winter ice in April to the end of June [17,18]. Trawl catches comprise up to $80 \%$ of the total catches of GoR herring at present, being concentrated in the ice-free period of the first half of the year (mostly until May), before the main trap-net fishery commences $[15,19]$. Trawl fishery prevails particularly in Latvian waters, while on the Estonian side, the share of trawl and trap-net fishery has remained close to equal over the recent period. GoR herring catches have been relatively stable, in the range of 26,000-32,000 tons since 2015, depending on the agreed TAC (total allowable catch), which has been limiting fishery since then [15].

In addition to the TAC restrictions, a number of technical measures have also been implemented by the Estonian and Latvian fisheries management authorities in order to achieve sustainable exploitation of the GoR herring. A 30-day ban of trawl fishery during the main spawning migration in spring has been imposed in both Latvia and Estonia, a summer ban of trawl fishery (from mid-June to September) in the Estonian part of the Gulf [15], the prohibition of fishing with trawls in waters of less than $20 \mathrm{~m}$ in depth, a maximum trawl height of $12 \mathrm{~m}$, and a minimum cod-end mesh size of at least $16 \mathrm{~mm}[20,21]$ serve as examples of such measures. These restrictions also include a maximum engine power limit of $300 \mathrm{HP}(221 \mathrm{~kW})$ for trawl vessels operating in the GoR, in order to avoid the deployment of large high-seas trawl vessels which might seriously affect the fragile ecosystem of the shallow and spatially restricted GoR [21].

The restriction of engine power has been applied since 1990, when the fleet consisted mostly of the so-called MRTK-type stern trawlers of 23-26 $\mathrm{m}$ in total length, with an engine power up to $221 \mathrm{~kW}$. Since the production of this vessel type was discontinued in 2010, the fishing companies inevitably face the need for upgrading to new vessels that come with more powerful engines. Modern, more powerful vessels are economically more effective, having a higher speed and a lower fuel consumption rate with the same number of crew. Thus, the engine power restriction currently in place hampers the technical modernization of trawl fleets, and companies operating in several areas need to maintain separate fleets for the GoR.

Defining the terms which contribute to the fishing effort has proven to be difficult and confusing. Two terms to quantify fishing effort, considering vessels using towed nets, have been most frequently identified: fishing capacity (engine power of gross tonnage), and fishing activity (days at sea or hours of fishing) [22,23]. Fishing mortality, as the most important factor describing the effect on the population, is classically linked to three variables: fishing capacity, fishing activity, and catchability coefficient. The latter includes the technical features of the gear and the fish accessibility [24]. The fishing capacity of trawlers is typically used in regulatory measures and is defined by the engine power of vessels, without considering the specifics of the gear used [25-27]. By ignoring the gear in fishing capacity measurements, the actual impact of fishing pressure (fishing mortality) may significantly change with modifications in gear and technological improvements (e.g., fish-finding sonar, stronger netting, changes in trawl panel design) [26]. Such factors do not change the measured capacity of vessels but, in combination, increase the actual capacity over time. Estimating the fishing pressure via the gear used seems more rational, but still not perfect, since other factors, such as towing speed and skippers' experience, also have an effect on the capture of mobile species [26-29].

The specifics of the topography of the GoR (mean depth $27 \mathrm{~m}$, maximum depth $60 \mathrm{~m}$ ) [30], define the limits of the vertical distribution of pelagic fish stocks. Despite 
that, juvenile herring distribution is closer to the surface layers, or in the upper parts, of herring schools [31,32]. Due to the specifics of the vertical distribution of herring schools in the GoR, it is more difficult to avoid catching juveniles from the surface layers. It has been demonstrated that an increased vertical opening of the trawl increases the catches [26]. Meanwhile, several other factors affecting trawl catches have been studied, but the results tend to be fishery-specific. Towing speed may have different effects on selectivity, depending on the species [33]. Results from a Danish trawl study even indicated that old, small vessels are more efficient than new, large ones [26], which may also be affected by e.g., skippers' experience [28]. Contradictory results indicate that the experiences of other fisheries are not simply transferrable, and specific problems require special studies [34-36].

The latest study of the potential effects of vessel size/engine power on catch composition in the GoR was conducted in the early 2000s [37]. During those studies, the structure of the experimental herring catches taken with two trawler types of different size and engine power (425 kW and $220 \mathrm{~kW}$ respectively), in November 2002 and April 2004, was analyzed. Using the common commercial gears of each vessel type (large vessels used large trawls), 14 trawl hauls with a duration of $30 \mathrm{~min}$ were performed during both experiments. The results indicated that the engine power and the technical parameters of the gears used had significant effects, not only on the size structure of the catches, but also on fishing mortality $[38,39]$. The results showed that the engine power together with the gear size affected the vertical opening of the trawl, which in turn resulted in differences in catch volume and structure. It was also observed that the effect of different engine power manifested clear seasonal effects; the share of juveniles appeared to be significantly higher in the catches of large vessels in the fall, while no differences were found in the spring. The authors of the study recommended that large vessels equipped with trawls with a vertical opening over $12 \mathrm{~m}$ should not be permitted in GoR herring fishery [37]. As a result, the restriction on vessel power was left unchanged and gear vertical opening was limited to $12 \mathrm{~m}$ in the respective legislation [20].

In the present study, we investigated the effects of vessels with different engine power, using the same gear and hauling technique. The effects of season, haul speed, depth, trawl vessel size, and catches on the (i) median weight and (ii) share of juvenile Baltic herring were investigated. We hypothesized that more powerful vessels do not cause harm to the stock when using the same gear as less powerful vessels.

\section{Materials and Methods}

The material used in this analysis was collected during a survey conducted with two different types of vessels, from feeding and overwintering grounds in the GoR (Baltic Sea, Figure 1). The spring-spawning herring in the GoR utilize the surveyed areas as feeding and overwintering grounds [40]. Parallel trawl hauls were conducted by vessels with different engine powers using gears of similar technical properties. The first vessel group (3 vessels) had a main engine power under $221 \mathrm{~kW}(117-221 \mathrm{~kW}$ ) (i.e., the maximum power allowed in the Gulf), and the second vessel group (4 vessels) contained engines exceeding the contemporary power limit (441-736 kW). A total of 40 successful hauls (20 hauls per vessel group) were conducted during the years 2019-2020. Since the distribution pattern and length composition of herring differ seasonally, the data were divided into two seasons: spring (April) and autumn/winter (September and January). Since herring undertake spawning migrations to shallow areas, and feeding migrations to the central part and out from the Gulf, the population under trawling pressure has a different structure depending on the season [16,32]. The spring survey was conducted in April 2019, and autumn-winter surveys took place in January and September 2020. The technical parameters (gear, location, trawl depth, hauling time, etc.) were kept as constant as possible between vessels. The gear used by both groups was a commercial pelagic trawl with a horizontal opening of $75 \mathrm{~m}$, a vertical opening of $12 \mathrm{~m}$, and a cod-end mesh size of $20 \mathrm{~mm}$, as is commonly used in GoR fishery. The exact trawling locations were chosen and agreed by the skippers, based on their experience, and information from echosounders (Figure 1). Hauling time was identical 
for both vessels $(2 \mathrm{~h})$, and the average speed remained in the range typically used in commercial fishing according to the vessel type. From all trawl hauls, 150-350 individuals were sampled for routine biological analysis, recording the total length, total weight, sex, and maturity stage.

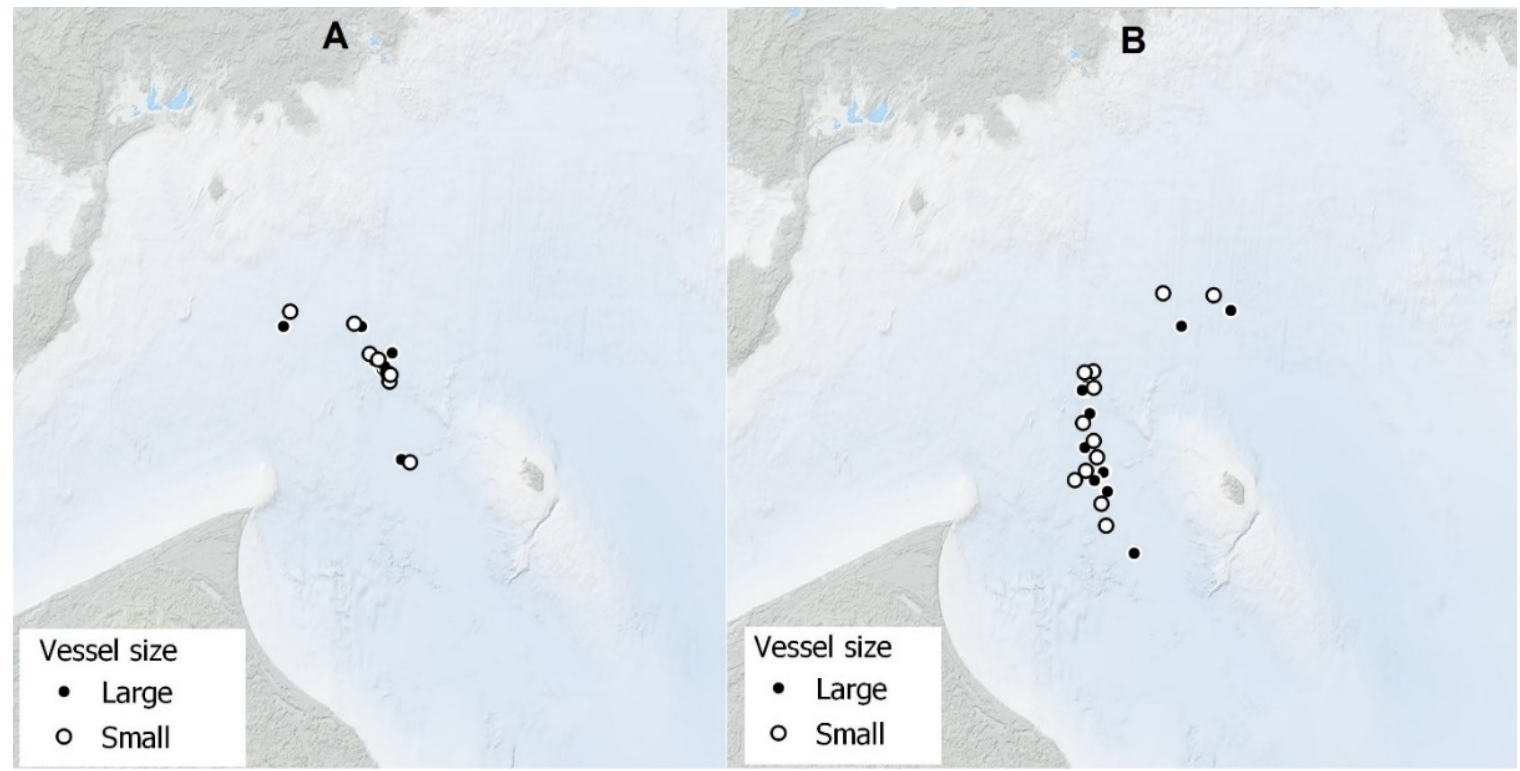

Figure 1. Location of trawl hauls by vessel group in the Gulf of Riga in the spring (A) and autumn/winter (B) seasons.

The percentage of juveniles and median weight of individuals (dependent variables) were calculated per experimental haul, using season-specific maturity ogives (spring and autumn/winter) [41]. The effects of depth, vessel size, vessel speed, and herring catch in tons (independent variables) were assessed using R statistical software [42] with nonparametric tests: Mann -Whitney U-test for categorical independent variables, and Spearman correlation for continuous independent variables. The response variables were the share of juveniles and the median weight of herring individuals in each catch. The effects of trawling season and vessel size on the share of juveniles in total herring catches were assessed. To calculate the share of juveniles in catches, the L50 maturity ogive was calculated from the spatio-temporally close commercial sampling data, using the "SizeMat" package in $\mathrm{R}$.

\section{Results}

The herring catch structures of the different vessels followed similar length frequency patterns in the spring (Kolmogorov-Smirnov test, $n=4845, \mathrm{D}=0.04, p=0.05$ ), but differed in the autumn/winter trials (Kolmogorov-Smirnov test, $n=5150, \mathrm{D}=0.24, p<0.001$, Figure 2). The trawling speed used was the typical working speed of each vessel, and varied due to the need to maintain a chosen trawl depth, which resulted in the higher speed of large vessels (LM, $n=40, \mathrm{R}^{2}=0.46, p<0.001$, Figure 3 ). The difference in hauling speed did not have a significant effect on our results (Spearman correlation, $n=40$, rho $=-0.05$, $p=0.83$. 

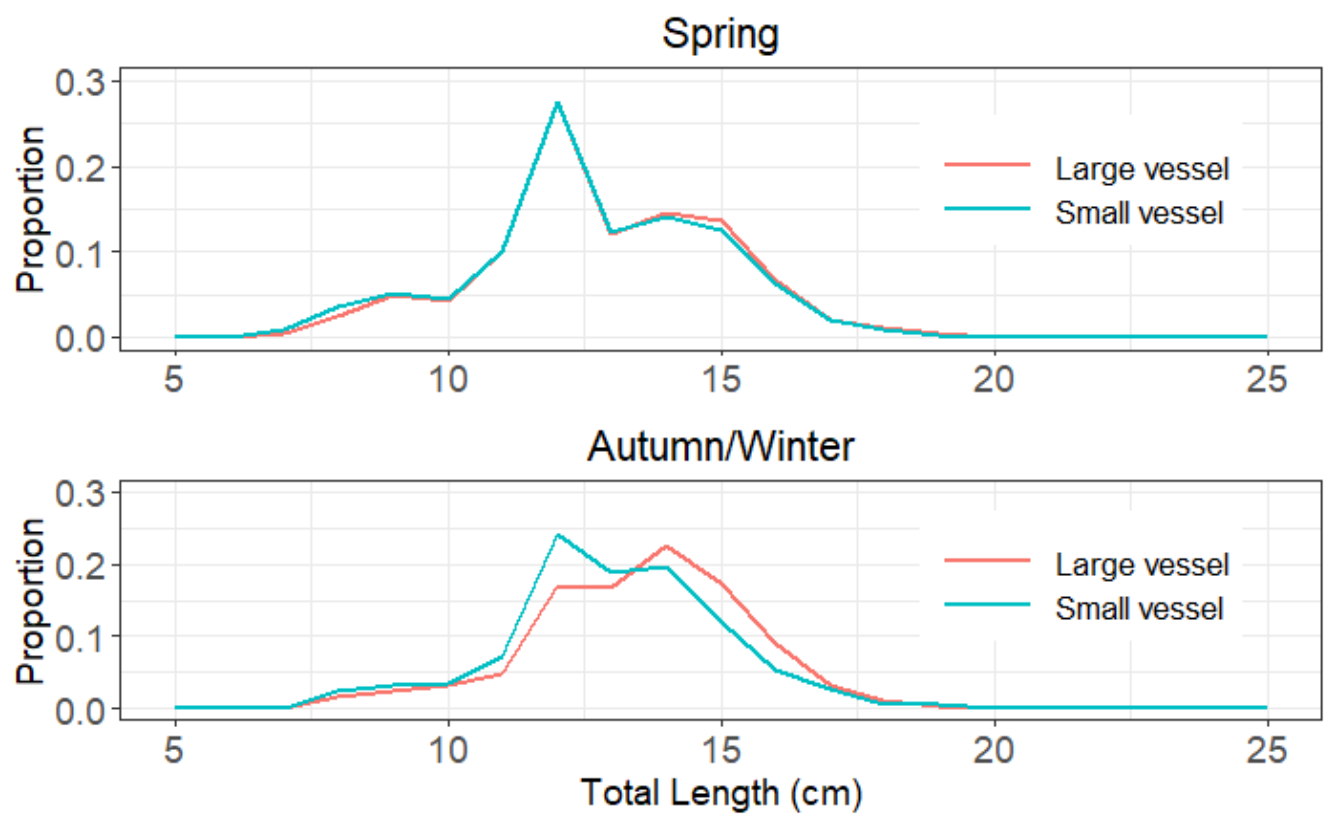

Figure 2. Comparison of Baltic herring length frequencies in different types of vessels (large vs small) in the spring and autumn/winter seasons (sample sizes: Spring/Large $=2523$, Spring $/$ Small $=2322$, Autumn $/$ Winter $/$ Large $=5150$, Autumn $/$ Winter $/$ Small $=2454$ ).
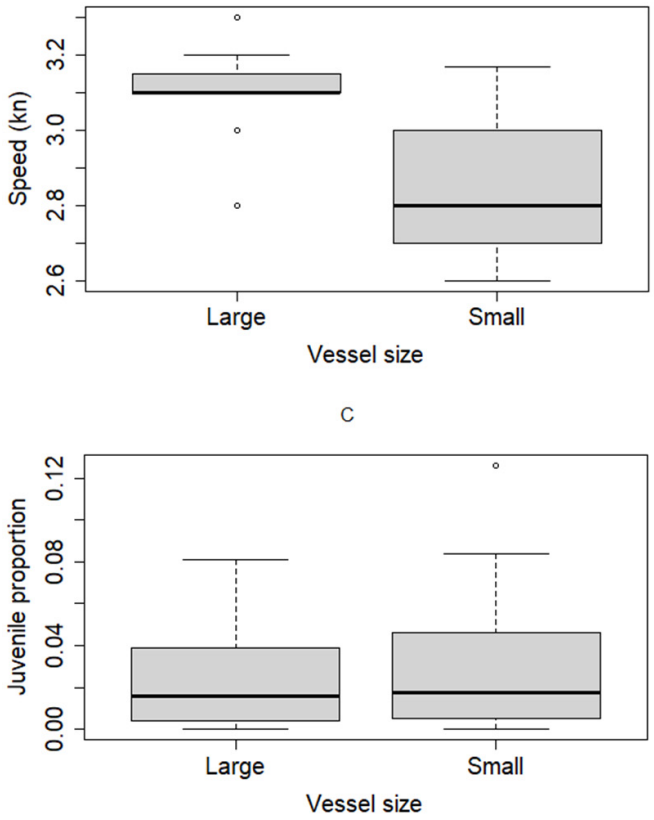

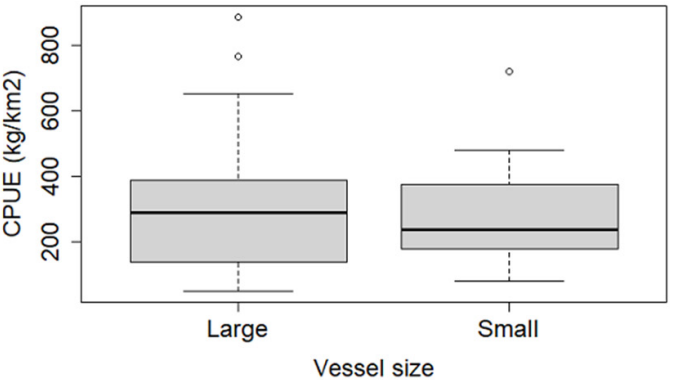

Figure 3. Boxplot of the median hauling speed (A), CPUE (B), and proportion of juveniles (by weight) (C) values for the large and small vessels. The horizontal bold lines show the median, shaded boxes indicate the interquartile ranges with upper and lower whiskers ( $5 \%$ and $95 \%)$.

The herring median weight in catches was higher in autumn/winter compared to spring (before spawning) (Mann-Whitney U-test, $n=40, \mathrm{~W}=339, p<0.001$ ). The effect of vessel size on the median weight was considerable only in autumn/winter, when the median weight was significantly higher in larger trawls (Mann-Whitney U-test, $n=16$, $\mathrm{W}=114, p=0.01$, Figures 4 and 5). 
A

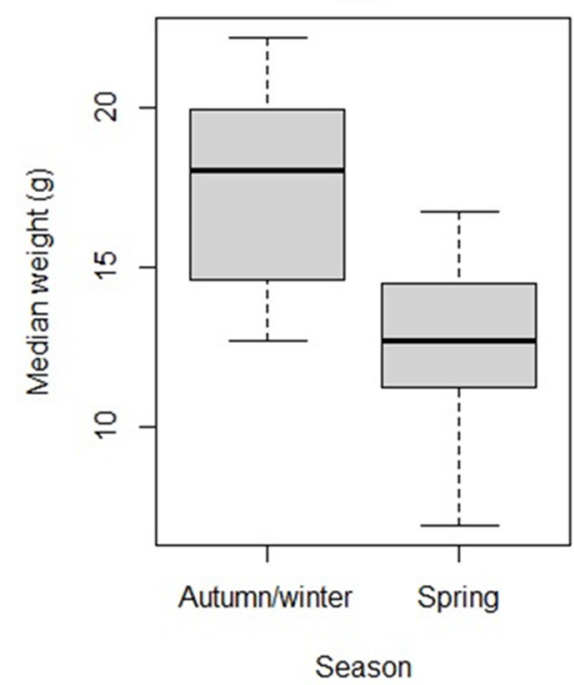

B

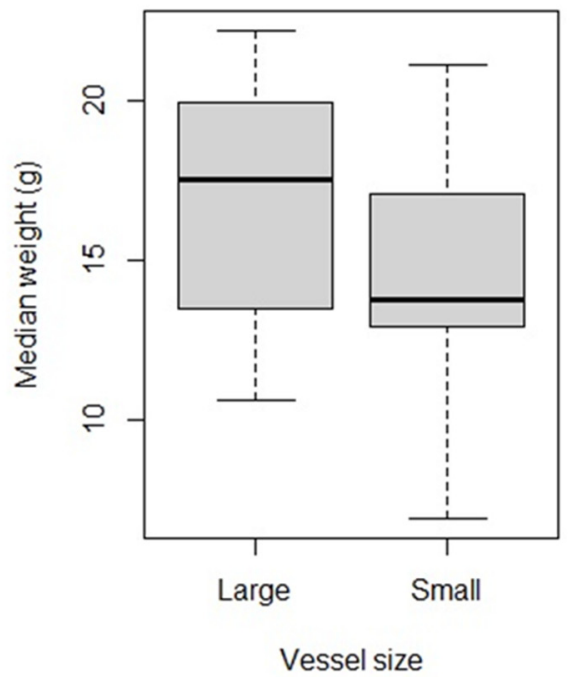

Figure 4. Boxplot of the herring median weight in catches (all vessels) by season (A), and vessel size (B). The horizontal bold lines show the median, shaded boxes indicate the interquartile ranges with upper and lower whiskers (5\% and 95\%).

A

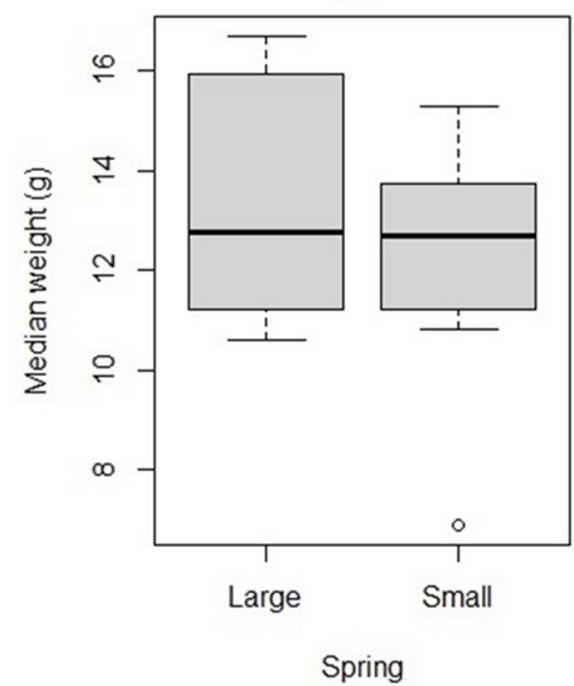

B

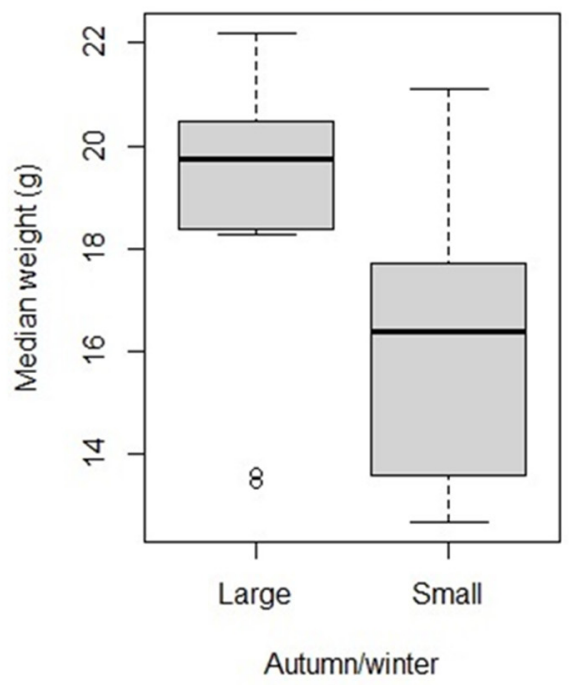

Figure 5. Boxplot of the median weight of individuals in catches of different vessels in spring (A), and autumn/winter (B). The horizontal bold lines show the median, shaded boxes indicate the interquartile ranges with upper and lower whiskers (5\% and 95\%). Please note the different scales on the Y-axis.

In order to calculate the share of juveniles in catches, L50 maturity values of $11.9 \mathrm{~cm}$ in autumn/winter, and $13.4 \mathrm{~cm}$ in spring were calculated using a commercial catch analysis of the same period/area. The share of juveniles in catches did not differ considerably between vessels, but was higher in the spring (Mann-Whitney U-test, $n=40, \mathrm{~W}=84, p=0.003$, Figure 6). Despite differences in trawling speed, this factor had no direct influence on the juvenile proportion (Spearman correlation, $n=40$, rho $=0.04, p=0.79$ ). 
A

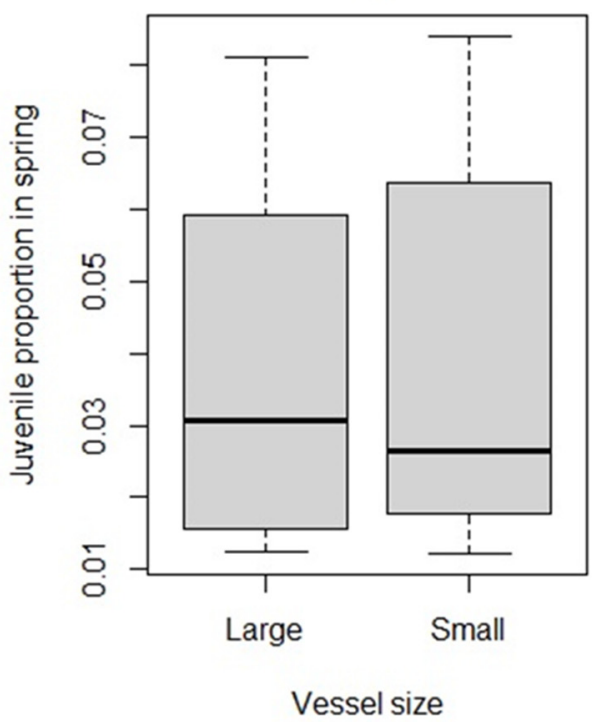

B

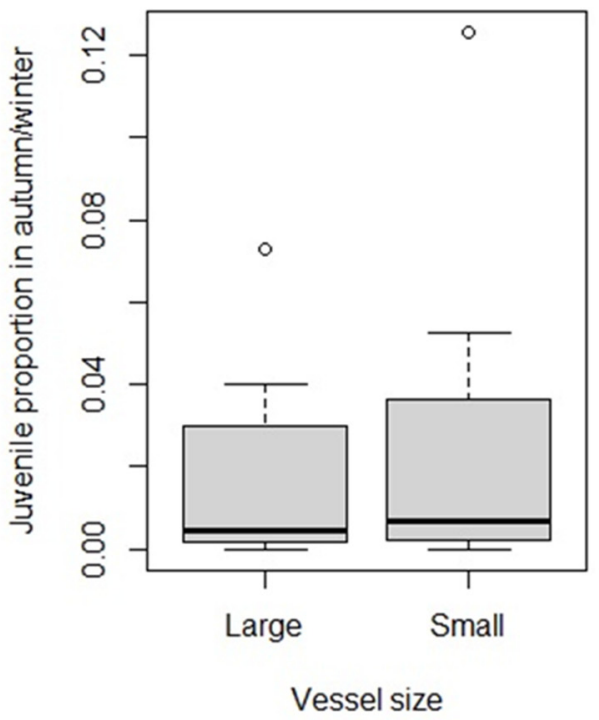

Figure 6. Boxplot of the share of juvenile individuals in catches of different vessels by season: spring (A) and autumn/winter (B). The horizontal bold lines show the median, shaded boxes indicate the interquartile ranges with upper and lower whiskers (5\% and 95\%). Please note the different scales on the Y-axis.

The total number of catches was more variable, but it was generally higher in the spring, as was the share of juveniles in catches (Figure 6). In the spring experiments, the juvenile share fluctuated, but on average was lower in deeper waters (Spearman correlation, $n=16$, rho $=-0.72, p<0.01$ ). In autumn/winter, the difference was not statistically significant (Spearman correlation, $n=24$, rho $=-0.13, p=0.55$ ). The juvenile share was significantly associated with water depth in the spring (Spearman correlation, $n=16$, rho $=-0.72, p=0.002$ ), and in the spring pooled with the autumn/winter (Spearman correlation, $n=40$, rho $=-0.33, p=0.038$ ).

\section{Discussion}

This study analyzed the effects of season, water depth, total catch size, and haul speed on the Baltic herring catch structure in vessels of different engine power. The motivation to conduct such a study relied on the fact that former research conducted in the 1990s showed a negative effect of large ( $>221 \mathrm{~kW}$ engine power) vessels on herring stock [37]. In our experiment, vessels with $>221 \mathrm{~kW}$ engine power with the same gear as currently used in the GoR displayed a comparable effect on the exploitation of the GoR herring stock as vessels with smaller engines. The results of the present study indicate that the median individual weight of herring is higher in autumn/winter, particularly in the catches of large trawlers. According to recent studies, older herring migrate earlier to spawning grounds. Therefore, the lower median weight in spring could be explained by the size-specific nature of herring spawning waves, with the largest individuals migrating earlier to spawning grounds $[16,43,44]$. The international management of the GoR herring stock and fishery are based on agreed weight-based catch quotas (total allowable catch -TAC). This means that the weight of individuals within a catch is an important factor affecting the resulting fisheries' mortality, since, in order to fish the quota, a larger number of individuals must be removed from the population if the individual weight is lower.

The sampling design in the present study was organized to provide comparable gear and haul locations for both types of vessels. Some differences are possible due to the skippers' behavior during trawling (fine tuning of the speed, gear depth, etc.) and the availability of information (more accurate sonar, trawl monitoring systems), which can lead to different decisions in fine-tuning the gear. The kilowatt power of the vessel's 
main engine is widely used as a proxy to characterize fishing capacity, however, this is not the most accurate measure of a vessel's ability to catch fish [25-27,45]. Catchability depends on several factors. Amongst other factors, technological developments, such as trawl monitoring systems and sonars, are estimated to increase the average catchability of commercial vessels by about $3 \%$ per year $[23,29]$. These findings are in correlation with our results, that vessel engine power is not the main descriptor of the differences between vessels' catch results.

The herring catches in the present study included on average $2 \%$ (by weight) of juveniles. Although this share of juveniles could be considered low, 658 million juvenile individual herring were removed from the GoR by commercial fishery in 2020 [46]. In addition to the bycatch of juveniles, there is a certain level of additional unaccounted mortality related to fish escaping through the meshes in the cod-ends of the trawl, which varies between 30 and 70\% in the northern Baltic Sea [8]. The results of the present study show that the juvenile bycatch is lower and the median length of retained herring higher in the autumn/winter season compared to the spring. Since the gear characteristics were the same in both seasons, the possibility of an increased share of unaccounted escapees in the autumn/winter can be excluded. In our experiments, the lowest bycatch rate of juveniles was in the catches of large vessels, surprisingly, although this difference was marginal. Additionally, juvenile bycatch displayed a strong seasonal effect. The bycatch of juveniles observed in the spring was five times higher compared to the autumn/winter ( $2.7 \%$ vs. $0.5 \%$ in weight, respectively). Former studies have demonstrated that the herring spawning season in the GoR begins with the spawning migration of older and bigger herring commencing their spawning migration towards shallow spawning grounds as early as April $[16,43,44]$. Hence, the higher share of juveniles observed in hauls in the spring can be explained by the migration of larger individuals into the near-coast spawning areas by the time of the survey in April (Figure 3). This might be an explanation for our results and calls for extra attention, considering the high negative pressure occurring in the spring for juveniles. Irrespective of the vessel size, the share of juvenile bycatch was higher in the spring in shallower areas. Therefore, the herring trawl fishery in the gulf during the autumn/winter period, and deeper areas, where the layers with higher number of juveniles could be avoided, would be preferable. Management measures to lower juvenile bycatch rates should therefore concentrate more on the seasonal aspects of fishery.

The sustainable management of commercial pelagic fish stocks is usually based on three main measures: TAC, areal/temporal closure and mesh size regulation $[13,47,48]$, targeting avoidance of young, immature individuals or disorientation of migrating prespawning schools. In the Gulf of Riga, trawl fishery is allowed in water depths of more than $20 \mathrm{~m}$, and with a mesh size no less than $16 \mathrm{~mm}$ [21]. Additionally, a 30-day ban on trawling is present during spring spawning, although the timing of the ban slightly differs between Estonia and Latvia. Studies of cod-end selectivity, using $20 \mathrm{~mm}$ mesh (as used in our experiment), showed that the 50\% selectivity length for Baltic herring is $8.0 \mathrm{~cm}$ [4]. Our results show that $50 \%$ maturation is observed at a total length of $12-13 \mathrm{~cm}$ and, therefore, current mesh size regulation is not effective in excluding juvenile bycatch. The regulation of mesh size to reduce juvenile bycatch in Baltic herring has been widely criticized for increasing the unaccounted mortality, due to the low survival of trawl escapees [5,7-9]. In studies of Bothnian Sea herring trawl fishery, it was assessed that more juvenile herrings are discarded underwater (escapees) than land, which strongly biases the mortality estimates [4]. Although there are no trawl escapement studies of herring in the GoR, the aforementioned findings suggest that changing the mesh size regulation would not have much effect on reducing juvenile mortality.

We found that the share of juveniles was mainly driven by the season and the depth of water in the trawling area. This phenomenon can be explained by the relative shallowness of the GoR, which determines the vertical and horizontal distributions of herring. Since juvenile herring tend to aggregate in the upper water layers and older individuals stay in the deep [16,31,32], the trawls with a higher vertical opening than currently allowed in the 
Gulf (12 m) [20] in shallow waters are not able to omit the juvenile fraction of schools. This interpretation is in accordance with a previous similar study conducted in the GoR, where large vessels with large trawl gear were proven to catch considerably higher amounts of juvenile herring [37]. By combining this information with our results, it can be concluded that the vertical opening of the trawl gear used in the GoR should not be increased.

Furthermore, our findings are in accordance with the suggestion of removing the engine power restriction from the Gulf.

The current results suggest that additional studies are needed to map the effect of gear parameters on herring stock, in relation to the depth structure of the fishing areas used by trawl fleets, in order to further optimize herring fishery and the stock management of GoR herring. Since the depth of water seems to affect the juvenile share of the catch, the decrease in vertical opening of the trawl net, or posing additional depth restrictions for gears with bigger opening, could potentially benefit the stock management and population status of the Baltic herring even further.

\section{Conclusions}

(1) Easing the maximum engine power restriction of the trawl vessels in the GoR itself will most likely not have a negative impact on the sustainable management of GoR herring stock;

(2) Trawl size (especially vertical opening size) should not increase with the possible introduction of larger vessels in the gulf.

Author Contributions: Conceptualization, all authors; methodology, T.R. and E.S.; software, E.S.; validation, E.S., T.A. and T.R.; formal analysis, E.S. and T.A.; investigation, T.R.; resources, M.V.; data curation, E.S. and T.R.; writing-original draft preparation, E.S.; writing-review and editing, all authors; visualization, E.S.; supervision, M.V. and T.R.; project administration, T.R. and M.V.; funding acquisition, M.V. All authors have read and agreed to the published version of the manuscript.

Funding: This research was funded by The European Maritime and Fisheries Fund (EMFF), grant nr 811017790005, "Impact of trawlers of different sizes on the Gulf of Riga ecosystem and fish stocks".

Institutional Review Board Statement: Not applicable.

Informed Consent Statement: Not applicable.

Data Availability Statement: Not applicable.

Acknowledgments: The authors would like to thank Andrus Hallang, Ain Lankov, Heli Shpilev, and all the crews of the vessels participating in the study for their support.

Conflicts of Interest: The authors declare no conflict of interest. The funders had no role in the design of the study; in the collection, analysis, or interpretation of data; in the writing of the manuscript, or in the decision to publish the results.

\section{References}

1. Bastardie, F.; Baudron, A.; Bilocca, R.; Boje, J.; Bult, T.P.; Garcia, D.; Hintzen, N.T.; Nielsen, J.R.; Petursdottir, G.; Sanchez, S.; et al. Evaluating biological robustness of innovative management alternatives. In Comparative Evaluations of Innovative Fisheries Management; Springer: Berlin/Heidelberg, Germany, 2009; pp. 119-142.

2. Rosenberg, A.A.; Kleisner, K.M.; Afflerbach, J.; Anderson, S.C.; Dickey-Collas, M.; Cooper, A.B.; Fogarty, M.J.; Fulton, E.A.; Gutiérrez, N.L.; Hyde, K.J.W.; et al. Applying a new ensemble approach to estimating stock status of marine fisheries around the world. Conserv. Lett. 2018, 11, e12363. [CrossRef]

3. Britten, G.L.; Duarte, C.M.; Worm, B. Recovery of assessed global fish stocks remains uncertain. Proc. Natl. Acad. Sci. USA 2021, 118. [CrossRef] [PubMed]

4. Rahikainen, M.; Peltonen, H.; Pönni, J. Unaccounted mortality in northern Baltic Sea herring fishery-magnitude and effects on estimates of stock dynamics. Fish Res. 2004, 67, 111-127. [CrossRef]

5. Suuronen, P. Mortality of Fish Escaping Trawl Gears; Food and Agriculture Organization: Rome, Italy, 2005 ; Volume 478.

6. EU. No. $1380 / 2013$ of the european parliament and of the council of 11 december 2013 on the common fisheries policy, amending council regulations (ec) no 1954/2003 and (ec) no 1224/2009 and repealing council regulations (ec) no 2371/2002 and (ec) no 639/2004 and council decision 2004/585/ec. Off. J. Eur. Union L 2013, 354, 22-61. 
7. Kuikka, S.; Suuronen, P.; Parmanne, R. The impacts of increased codend mesh size on the northern Baltic herring fishery: Ecosystem and market uncertainties. ICES J. Mar. Sci. 1996, 53, 723-730. [CrossRef]

8. Suuronen, P.; Erickson, D.L.; Orrensalo, A. Mortality of herring escaping from pelagic trawl codends. Fish. Res. 1996, 25, 305-321. [CrossRef]

9. Suuronen, P.; Perez-Comas, J.A.; Lehtonen, E.; Tschernij, V. Size-related mortality of herring (Clupea harengus L.) escaping through a rigid sorting grid and trawl codend meshes. ICES J. Mar. Sci. 1996, 53, 691-700. [CrossRef]

10. Ojaveer, E. Population structure of pelagic fishes in the Baltic. Rapp. P-V Réun. Cons. Int. Explor. Mer. 1989, 190, 17-21.

11. Ojaveer, H.; Jaanus, A.; MacKenzie, B.R.; Martin, G.; Olenin, S.; Radziejewska, T.; Telesh, I.; Zettler, M.L.; Zaiko, A. Status of biodiversity in the Baltic Sea. PLoS ONE 2010, 5, e12467. [CrossRef]

12. Raid, T.; Kornilovs, G.; Lankov, A.; Nisumaa, A.-M.; Shpilev, H.; Järvik, A. Recruitment dynamics of the Gulf of Riga herring stock: Density-dependent and environmental effects. ICES J. Mar. Sci. J. Cons. 2010, 67, 1914-1920. [CrossRef]

13. Raid, T.; Arula, T.; Kaljuste, O.; Sepp, E.; Järv, L.; Hallang, A.; Shpilev, H.; Lankov, A.; Dejhalla, R.; Pavletic, D. Dynamics of the commercial fishery in the Baltic Sea: What are the driving forces? In Towards Green Marine Technology and Transport, Proceedings of the 16th International Congress of the International Maritime Assotiation of the Mediterranean (IMAM 2015), Pula, Croatia, 21-24 September 2015; Taylor \& Facncis Group: London, UK, 2015; pp. 897-906.

14. Raid, T.; Kaljuste, O. Towards better understanding of successful management of the Gulf of Riga herring stock. Hydrobiologia 2006, 554, 131-136. [CrossRef]

15. ICES. Report of the Baltic Fisheries Assessment Group (WGBFAS). ICES Sci. Rep. 2020, 2, 642. [CrossRef]

16. Ojaveer, E.; Pihu, E.; Saat, T. Fishes of Estonia; Estonian Academy Publishers: Tallinn, Estonia, 2003.

17. Rannak, L. On the recruitment to the stock of the spring spawning herring in the North-eastern Baltic. Rapp. P-V Réun. Cons. Int. Explor. Mer. 1971, 160, 76-82.

18. Rannak, L. On the factors determining the abundance of the spring spawning herring of the Eastern Baltic. Rapp. P-V Réun. Cons. Int. Explor. Mer. 1974, 166, 145-149.

19. Järvik, A.; Raid, T.; Sadul, J.-V.; Järv, L. Overexploitation of Fish Resources and Small-Scale Fisheries in the Northeastern Baltic Sea: Social Aspects of Ecosystem-Based Fisheries Management in the West Estonian Archipelago; Kruse, G.H., Browman, H.I., Cochrane, K.L., Evans, D., Jamieson, G.S., Livingston, P.A., Woodby, D., Zhang, C.I., Eds.; Global Progress in Ecosystems-Based Fisheries Management: Fairbanks, AK, USA, 2012; pp. 257-272.

20. Fishing Regulations. Riigi Teataja. 2016. Available online: https://www.riigiteataja.ee/akt/128122016010?leiaKehtiv (accessed on 4 January 2022).

21. Regulation (EU). Consolidated Text: Regulation (EU) 2019/1241 of the European Parliament and of the Council of 20 June 2019 on the Conservation of Fisheries Resources and the Protection of Marine Ecosystems through Technical Measures, Amending Council Regulations (EC) No 1967/2006, (EC) No 1224/2009 and Regulations (EU) No 1380/2013, (EU) 2016/1139, (EU) 2018/973, (EU) 2019/472 and (EU) 2019/1022 of the European Parliament and of the Council, and repealing Council Regulations (EC) No 894/97, (EC) No 850/98, (EC) No 2549/2000, (EC) No 254/2002, (EC) No 812/2004 and (EC) No 2187/2005. 2019. Available online: http:/ / data.europa.eu/eli/reg/2019/1241/2021-01-01 (accessed on 4 January 2022).

22. Bell, J.D.; Watson, R.A.; Ye, Y. Global fishing capacity and fishing effort from 1950 to 2012. Fish Fish. 2017, 18, 489-505. [CrossRef]

23. Palomares, M.L.; Pauly, D. On the creeping increase of vessels' fishing power. Ecol. Soc. 2019, 24.

24. Pascoe, S.; Gréboval, D.F. Measuring Capacity in Fisheries; Food \& Agriculture Organization: Rome, Italy, 2003.

25. Marchal, P.; Andersen, B.; Caillart, B.; Eigaard, O.; Guyader, O.; Hovgaard, H.; Iriondo, A.; Le Fur, F.; Sacchi, J.; Santurtún, M. Impact of technological creep on fishing effort and fishing mortality, for a selection of European fleets. ICES J. Mar. Sci. 2007, 64, 192-209. [CrossRef]

26. Eigaard, O.R.; Rihan, D.; Graham, N.; Sala, A.; Zachariassen, K. Improving fishing effort descriptors: Modelling engine power and gear-size relations of five European trawl fleets. Fish Res. 2011, 110, 39-46. [CrossRef]

27. Marchal, P.; Andersen, B.; Bromley, D.; Iriondo, A.; Mahévas, S.; Quirijns, F.; Rackham, B.; Santurtún, M.; Tien, N.; Ulrich, C. Improving the definition of fishing effort for important European fleets by accounting for the skipper effect. Can. J. Fish Aquat. Sci. 2006, 63, 510-533. [CrossRef]

28. Eigaard, O.R.; Marchal, P.; Gislason, H.; Rijnsdorp, A.D. Technological development and fisheries management. Rev. Fish Sci. Aquac. 2014, 22, 156-174. [CrossRef]

29. Marchal, P.; Ulrich, C.; Korsbrekke, K.; Pastoors, M.; Rackham, B. A comparison of three indices of fishing power on some demersal fisheries of the North Sea. ICES J. Mar. Sci. 2002, 59, 604-623. [CrossRef]

30. Ojaveer, H. Composition and Dynamics of Fish Stocks in the Gulf of Riga Ecosystem; Tartu University Press: Tartu, Estonia, 1997.

31. Ojaveer, H.; Kalejs, M.V. On some oceanographic prerequisites that determine the abundance and distribution of pelagic fish in the Baltic Sea. Oceanology 1974, 14, 451-459.

32. Ojaveer, E. Läänemeri. Teaduste Akadeemia Kirjastus. 2014, p. 387. Available online: http://vana.kirj.ee/10588/ (accessed on 4 January 2022).

33. Dahm, E.; Wienbeck, H.; West, C.W.; Valdemarsen, J.W.; O'neill, F.G. On the influence of towing speed and gear size on the selective properties of bottom trawls. Fish Res. 2002, 55, 103-119. [CrossRef] 
34. Mahévas, S.; Vermard, Y.; Hutton, T.; Iriondo, A.; Jadaud, A.; Maravelias, C.D.; Punzón, A.; Sacchi, J.; Tidd, A.N.; Tsitsika, E.V.; et al. An investigation of human vs. technology-induced variation in catchability for a selection of European fishing fleets. ICES J. Mar. Sci. 2011, 68, 2252-2263. [CrossRef]

35. Reid, D.G.; Graham, N.; Rihan, D.J.; Kelly, E.; Gatt, I.R.; Griffin, F.; Gerritsen, H.D.; Kynoch, R.J. Do big boats tow big nets? ICES J. Mar. Sci. 2011, 68, 1663-1669. [CrossRef]

36. Manjarres-Martinez, L.M.; Gutierrez-Estrada, J.C.; Hernando, J.A. Effects of mesh size and towing speed on the multispecies catch rates of historical swept area surveys. Fish Res. 2015, 164, 143-152. [CrossRef]

37. Järvik, A.; Raid, T.; Shpilev, H.; Järv, L.; Lankov, A. Precautionary approach in Baltic herring trawl fishery: The effect of hauling techniques and engine power on unaccounted mortality estimates. In Proceedings of the 12th International Congress of the Association of the Mediterranean, Lisboa, Portugal, 26-30 September 2005; pp. 1223-1330.

38. Raid, T.; Shpilev, H.; Järv, L.; Järvik, A. Towards sustainable Baltic herring fishery: Trawls vs. pound nets. In Sustainable Maritime Transportation and Exploitation of Sea Resources; Taylor \& Francis Ltd.: London, UK, 2011; pp. 1055-1060.

39. Raid, T.; Järv, L.; Hallang, A.; Shpilev, H.; Kaljuste, O.; Järvik, A. Managing the Spatial and Temporal Pattern of Baltic Herring Trawl Fishery: A Potential Tool for Sustainable Resource Management? 2014. Available online: https:/ / www.semanticscholar.org/ paper/Managing-the-spatial-and-temporal-pattern-of-Baltic-Raid-J\%C3\%A4rv / ed405c85acbf35959589bcacffe098f2f1f77f45 (accessed on 4 January 2022).

40. Ojaveer, E. Reproduction biology of autumn herring in the Gulf of Riga. Tr. Balt. Nautchno-Issledovatelskogo Inst. Rybn. Hozjaistva 1970, 4, 205-227.

41. ICES. Report of the Workshop on Sexual Maturity Staging of Herring and Sprat (WKMSHS); Report No.: ICES CM 2011/ACOM:46; ICES: Charlottenlund, Denmark, 2011; p. 143.

42. R Core Team. A Language and Environment for Statistical Computing; R Foundation for Statistical Computing: Vienna, Austria, 2021. Available online: http:/ / www.R-project.org/ (accessed on 4 January 2022).

43. Lambert, T.C. The effect of population structure on recruitment in herring. ICES J. Mar. Sci. 1990, 47, 249-255. [CrossRef]

44. Arula, T.; Shpilev, H.; Raid, T.; Sepp, E. Thermal conditions and age structure determine the spawning regularities and condition of Baltic herring (Clupea harengus membras) in the NE of the Baltic Sea. PeerJ 2019, 7, e7345. [CrossRef]

45. Rasmus Nielsen, J.; Sparre, P.J.; Hovgrd, H.; Frost, H.; Tserpes, G. Chapter 7 Effort and capacity-based fisheries management. In Developments in Aquaculture and Fisheries Science; Motos, L., Wilson, D.C., Eds.; Elsevier: Amsterdam, The Netherlands, 2006; pp. 163-216. Available online: https:/ / www.sciencedirect.com/science/article/pii/S0167930906800104 (accessed on 4 January 2022).

46. ICES. Baltic Fisheries Assessment Working Group (WGBFAS). 2021, p. 717, Report No.: 3:53. Available online: https://www.ices. $\mathrm{dk} /$ sites / pub /Publication\%20Reports/Forms /DispForm.aspx?ID=38028 (accessed on 4 January 2022).

47. Housholder, D.J. Evaluation of Harvest Control Rules: Simple One-Parameter vs. Complex Multi-Parameter Strategies. Ph.D. Thesis, The University of Bergen, Bergen, Norway, 2004.

48. Zableckis, S.; Raid, T.; Arnason, R.; Murillas, A.; Eliasen, S.; Sverdrup-Jensen, S.; Kuzebski, E. Costs of management in selected fisheries. In Comparative Evaluations of Innovative Fisheries Management; Springer: Berlin/Heidelberg, Germany, 2009; pp. 191-210. 